\title{
Future (im)perfect? \\ Mapping conflict, violence and extremism in Africa Jakkie Cilliers
}

\section{Summary}

The central challenge for sub-Saharan Africa is to build accountable, capable governments that can deliver security and inclusive growth. Research into the drivers, trends and characteristics of violence in Africa may help achieve these goals. This paper firstly presents global and African trends in armed conflict since 1960, while looking at armed conflict within the broader context of political violence using recent event data. The fatality burden between key affected countries is also discussed. The paper then turns to an examination of the high levels of non-state conflict in the Middle East and Africa compared to the rest of the world and the systemic imbalances that drive instability. Finally, challenges in measuring the relative contribution of violent Islamist extremism to political violence are presented.

THIS PAPER EXPANDS on the analysis presented in a number of previous publications by the Institute for Security Studies (ISS) ${ }^{1}$ on the drivers of conflict and instability in Africa. Apart from contextual analyses from a variety of sources, the paper relies on data from three large conflict data providers, namely the Uppsala Conflict Data Program (UCDP) at the Uppsala University in Sweden, ${ }^{2}$ the Armed Conflict Location and Event Data Project (ACLED) at the University of Sussex ${ }^{3}$ and the Global Terrorism Database (GTD) hosted by the University of Maryland in the USA. ${ }^{4}$

The first section presents global and African trends in armed conflict since 1960. It then moves on in the second section to place armed conflict within the broader context of political violence using more recent event data. Absolute fatality or event data at country level can, however, be quite misleading given the large disparities in population size between countries such as Nigeria and Somalia. The third section therefore presents an analysis of the fatality burden between key affected countries per 100000 people to provide a comparable measure of the 'conflict burden' at national level. The paper then examines the high levels of non-state conflict in the Middle East and Africa compared to the rest of the world. This analysis introduces an examination of the systemic imbalances that drive instability in Africa. For reasons that relate to history, culture and geography, a broad distinction is made between sub-Saharan Africa, ${ }^{5}$ North Africa ${ }^{6}$ and the Middle East. ${ }^{7}$ 
The final section deals with the challenges of measuring the relative contribution of violent Islamist extremism to political violence.

\section{Trends in armed conflict globally and in Africa}

When considering levels of conflict in a country or indeed globally, it is important to consider population size. A more crowded world is inevitably more turbulent, particularly in those regions with large cohorts of young people without jobs or prospects. It can therefore be expected that a world with 7.2 billion people (the estimate for 2015) will have more deaths as a result of armed conflict than a world with only 3 billion people (the global population in 1960).

A number of authors, most notably Steven Pinker ${ }^{8}$ and Andrew Mack, ${ }^{9}$ have written extensively about the long-term trend of increasing numbers of people dying of disease and old age while those dying from armed violence are steadily decreasing over time. This is a trend visible over centuries and generations rather than decades or years since annual deaths from armed conflict inevitably fluctuate. An important reason for this historical decline is the division of the world into increasingly stable territorial states with defined and accepted international boundaries. This, and the commensurate reduction in interstate armed conflict in line with the entrenchment of global norms against war between states, largely explains the reductions in deaths from armed conflict.

Attempts to change borders, such as is currently occurring between Russia and the Ukraine, or between Ethiopia and Eritrea some years ago, still happen but are relatively rare. Since borders are largely set, most armed conflicts today are internal rather than between states. In general, the move from interstate to intrastate armed conflict largely explains the reduction in fatalities since war between countries is far more deadly and destructive than armed conflict within countries. The former are fought by organised armed forces trained and equipped for this deadly task.

Figure 1: Annual number of armed conflicts vs population size for the world, $1960-2014$

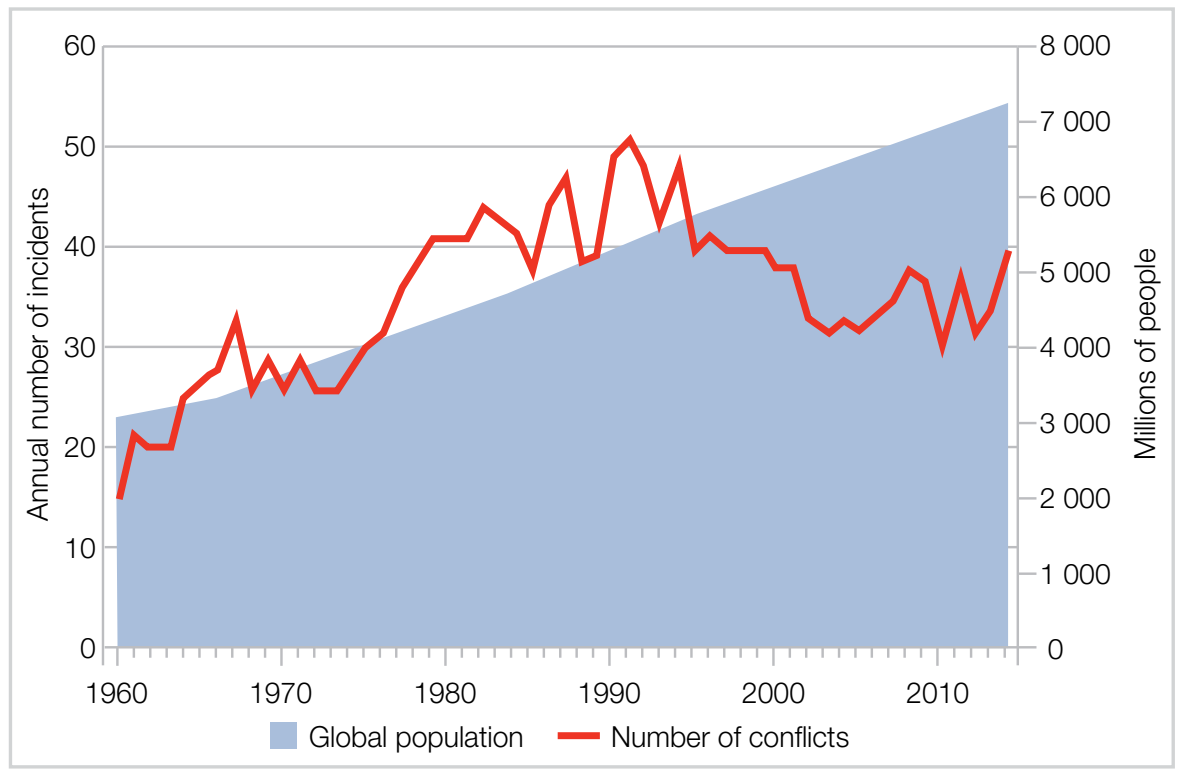

Source: UCDP/PRIO Armed Conflict Dataset v. 4-2015, 1946 - 2014, www.pcr.uu. se/research/ucdp/ datasets/ucdp_prio_armed_conflict_dataset (accessed 10 July 2015), overlain with United Nations Development Programme (UNDP) historical population data. 
An example of the violent impact of efforts to redefine borders can currently be seen in conflict in Iraq and Syria where the Islamic State is challenging the status quo ante.

Taking a shorter historical view than the trends discussed in the preceding paragraphs, Figure 1 is an overlay of the number of armed conflicts (as measured by the UCDP/PRIO Armed Conflict Dataset) and the increase in global population from 1960 to $2014 .{ }^{10}$ As tension between the former Warsaw Pact countries and the West mounted, the burden of global armed conflict increased, even after taking the population increase into account, to reach unprecedented high levels with peaks in 1982 and 1987. After a spurt of violence that released the pressure that had built up during the Cold War, Figure 1 captures the peace dividend from 1991. Although the number of incidents only correlates to fatalities in a general sense (at levels of 25 and 1000 or more per incident) the trend line is a good general indicator of conflict.

\section{The global burden of fatalities from armed conflict slowly decreases when trends are reviewed over long time horizons and in relation to population size}

Large annual oscillations become evident from 2007, and from 2012 armed conflict appears to be on the increase, driven in part by the War on Terror and its fallout. Some regions (Central America in particular) have also seen sharp increases in fatalities from organised crime, with the violence between drug cartels in Mexico approaching casualty levels generally associated with a civil war. ${ }^{11}$

Recent trends have reversed some of the relative gains in the reduction of armed-conflict levels that followed the collapse of the Berlin Wall in 1989, but, in general, Figure 1 reaffirms that the global burden of fatalities from armed conflict slowly decreases when trends are reviewed over long time horizons and in relation to population size.

Figure 2: Percentage of armed conflict incidents and population for Africa, 1960 - 2014

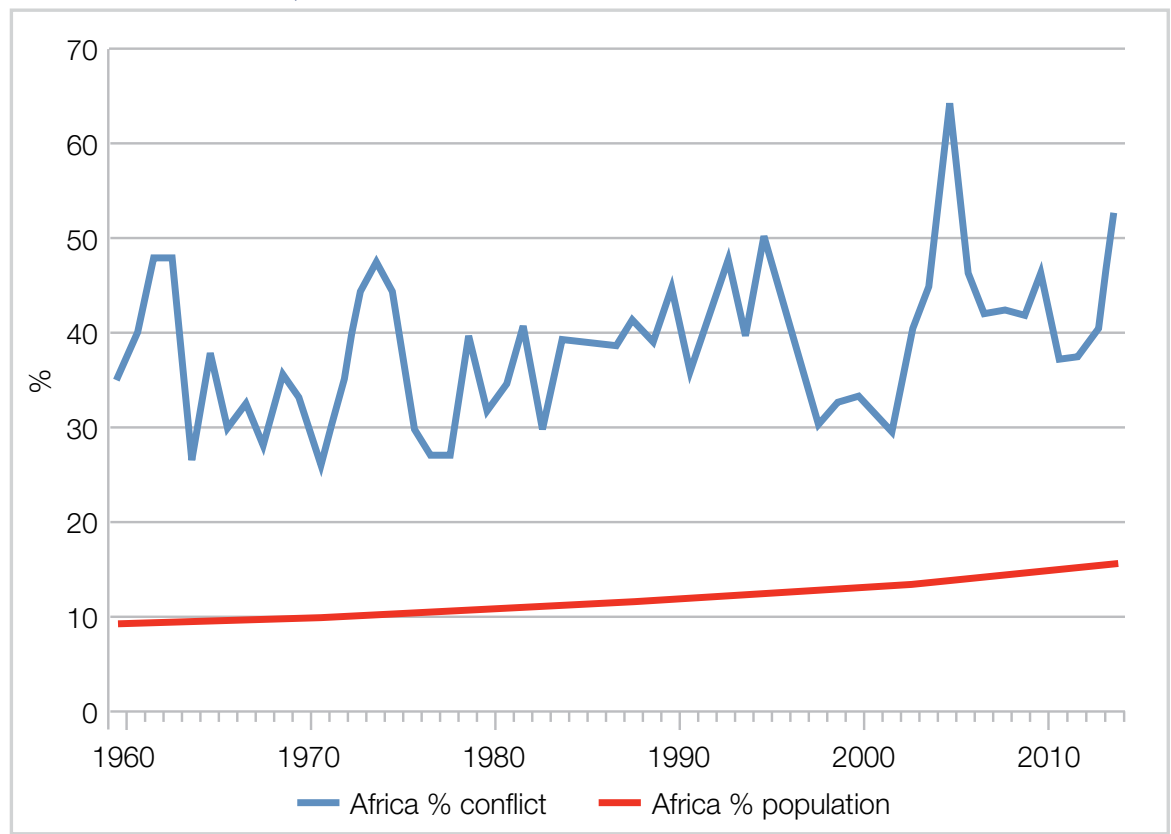

Source: Uppsala/Prio Armed Conflict Dataset, v. 4-2015. Population from International Futures. 
Figure 2 presents Africa's population as a percentage of global population and Africa's armed conflict burden as a percentage of the global armed conflict burden (using the same UCDP dataset used for Figure 1). From this it is clear that Africa's conflict burden is significantly higher than the global average. In addition, large annual oscillations are evident. Since Africa's share of global conflict remains constant over time (despite the sharp annual oscillations), the continent experienced the same global rise and an eventual general decline of armed conflict over time, as depicted in Figure 1.

During the period 1989 to 2015, i.e. from the end of the Cold War, Africa's population almost doubled, increasing by an estimated $89 \%$ (or by 546 million people) to 1159 million. In 1989, Africa had 12\% of the world's population and 39\% of its armed-conflict incidents. By 2014 Africa had 16\% of the world's population and $52 \%$ of the world's armed-conflict incidents, a hefty increase from just $40 \%$ the previous year.

\section{Graphic images of extreme violence have elevated the importance of al-Qaeda and the Islamic State to levels above their actual size, strength and impact}

While armed conflict globally appears to be declining when compared to population size, other types of violence follow a different trend. Certainly, the rise of social media and the 24-hour news cycle create the impression of a world in turmoil. The everpresent camera, now on every smart phone, ensures the global circulation of graphic images of war and conflict. Social media accentuate this view by conveying intense personal views, emotions and observations that are recycled globally. This trend is vitally important in the case of violent Islamist extremism. Al-Qaeda and the Islamic State, the two best known global brands, are dependent on relaying violence porn through mainstream media (e.g. television), social media (e.g. Twitter, YouTube and Facebook) and the World Wide Web for their growth and reputation. Videos and graphic images of brutal beheadings, torture and extreme violence have helped to elevated the relative importance of these movements to levels completely out of proportion to their actual size, strength and impact.

The move towards global multi-polarity is accentuating the sense of drift and turmoil.12 In a world where war between countries is seldom officially declared and where the nature of organised violence has changed, the dividing line between armed conflict, organised crime and extremist political violence/terrorism has become blurred. While large scale armed conflict, with its associated high number of fatalities, is likely to continue its steady decline when reviewing trend lines over long-term horizons, the short-term implications of the increase in social instability, protests and terrorism are less clear.

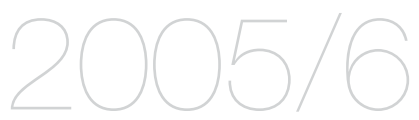

FATALITIES AND POLITICAL VIOLENT EVENTS DECLINE TO THEIR LOWEST LEVELS, BEFORE INCREASING AGAIN

\section{Political violence vs fatalities}

Whereas the UCDP gathers data on each incident where 25 or more battle-related deaths occur during a single year per dyad, i.e. between two specific conflicting parties, ACLED gathers more granular politically violent event data in Africa. Figure 3 is a summary of the ACLED data on fatalities (left-hand scale) and events (right-hand scale) from political violence between 1997 and 2014. The spike of 193751 fatalities 
Figure 3: Politically violent events and fatalities in Africa, 1997 - 2014

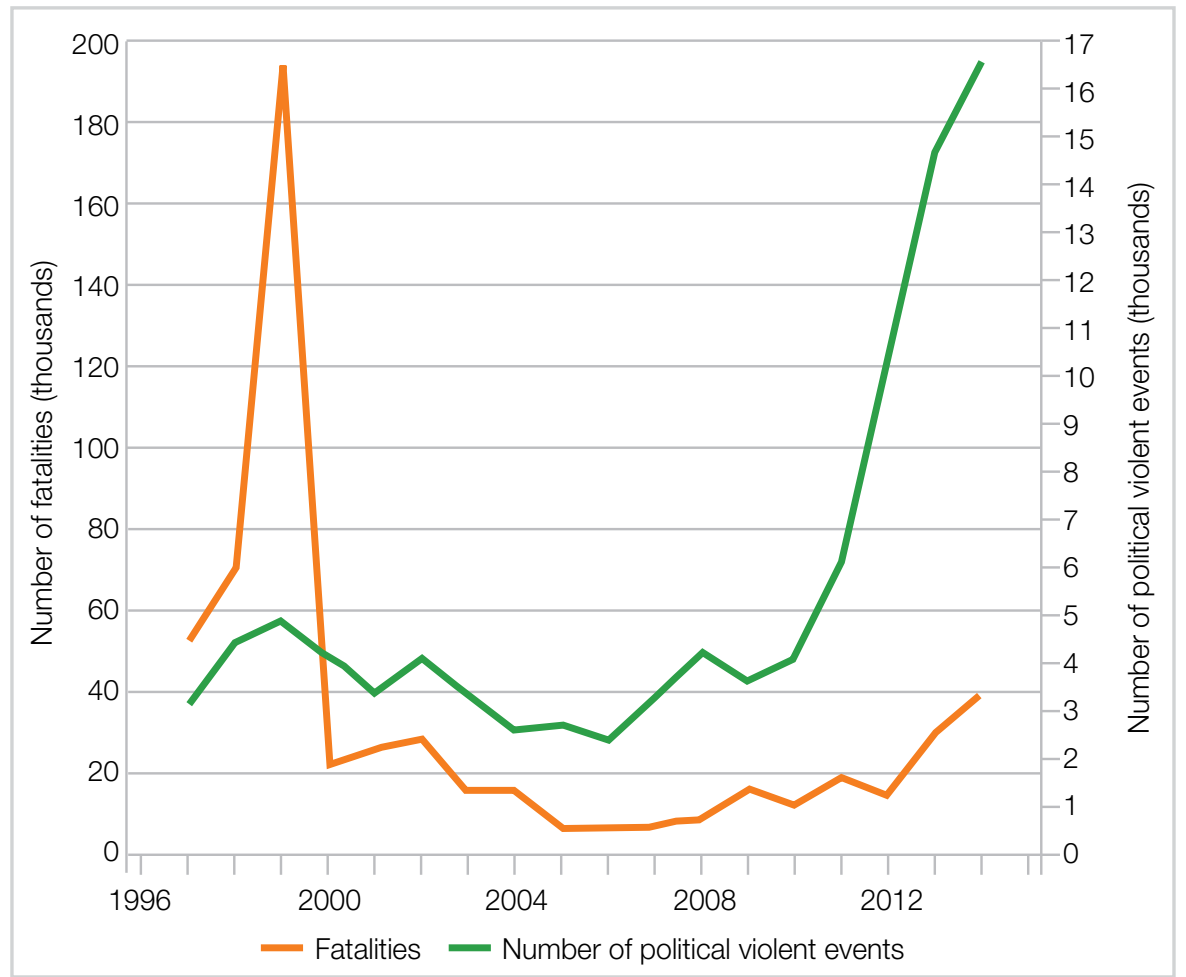

Source: ACLED, Version 5, 1997 - 2014.

recorded in 1999 is the result of 73978 fatalities recorded in Angola, ${ }^{13}$ and 77305 fatalities in Eritrea and 26421 in neighbouring Ethiopia during their interstate border war over the town of Badme. The level of fatalities is consistently much higher than the number of politically violent events. Both fatalities and the number of political violent events declined to their lowest levels in 2005/2006 before increasing again.

It is important to acknowledge that the rise in a global, interconnected world may have increased reporting rates and that by 2014 the ability of projects such as ACLED to track events may have improved. Improvements in reporting rates may thus contribute to increases in event figures.

Figure 4 presents the trends for three broad categories of politically related conflicts from January 2000 to August 2015, using the same event data ACLED used for the event graph in Figure 3, but it now reflects monthly totals and extends the data to the end of August 2015. Different from the UCDP data, there is no fatality threshold in the data gathered by ACLED. The absence of fatalities as an unambiguous 'marker' inevitably reduces the reliability of some aspects and categories of data but the disaggregated nature of the data is valuable for trend analysis. Social turbulence in Africa has clearly increased from the end of $2010 .{ }^{14}$

A summation of the trend in each of the three categories of incidents reveals an increase from an average of around 10 events per day at the end of 2011 to four times that level by the middle of 2015. Levels of reported daily fatalities have also increased during the post-2010 period. Daily fatalities are consistently at a much higher level than daily events, and have followed a U-shaped pattern after the end of the Cold War (from around 1990) to reach its lowest average from 2005 to the end of 2009 at

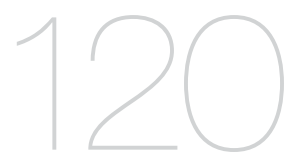

FATALITIES PER DAY AT THE END OF 2014 (UP FROM 20 PER DAY FROM 2005 - 2009) 
around 20 fatalities per day, before increasing sharply to the end of 2014 to around 120 per day, but levelling off during the first half of 2015.

From a much lower base the fourfold increase in conflict-related political events has thus broadly been accompanied by a fourfold increase in fatalities. These trends are broadly in line with the trends in armed violence discussed above based on UCDP/ $\mathrm{PRIO}$ data, therefore providing a degree of confidence in the trends. Whereas in 1998, events in Angola, the Democratic Republic of Congo (DRC) and Sierra Leone dominated, in 2014 events in the Central African Republic (CAR), the DRC, Egypt, Libya, Nigeria, South Africa, South Sudan and Sudan all represent a significant portion of events. The increase in events therefore occurs quite broadly across a number of African countries, including countries that were impacted by the Arab Spring (e.g. Egypt and Libya), rebel activity (the CAR, Sudan, South Sudan and the DRC), terrorism (Nigeria and Somalia), and riots (South Africa). In addition, in 2014 Egypt, Libya, Tunisia and South Africa had presidential or general elections, occurrences that probably increase the number of politically violent events since they push up the political temperature.

Despite the concurrent increase in fatality and event levels, the relationship between these two trends is complex and differs regionally and country by country. Thus, the Arab Spring and political turbulence in countries such as South Africa increased political conflict events sharply but did not result in commensurate increases in fatalities. However, simultaneous increases in fatalities did occur in countries such

Figure 4: Monthly events in Africa: January 2008 - August 2015 (stacked area graph)

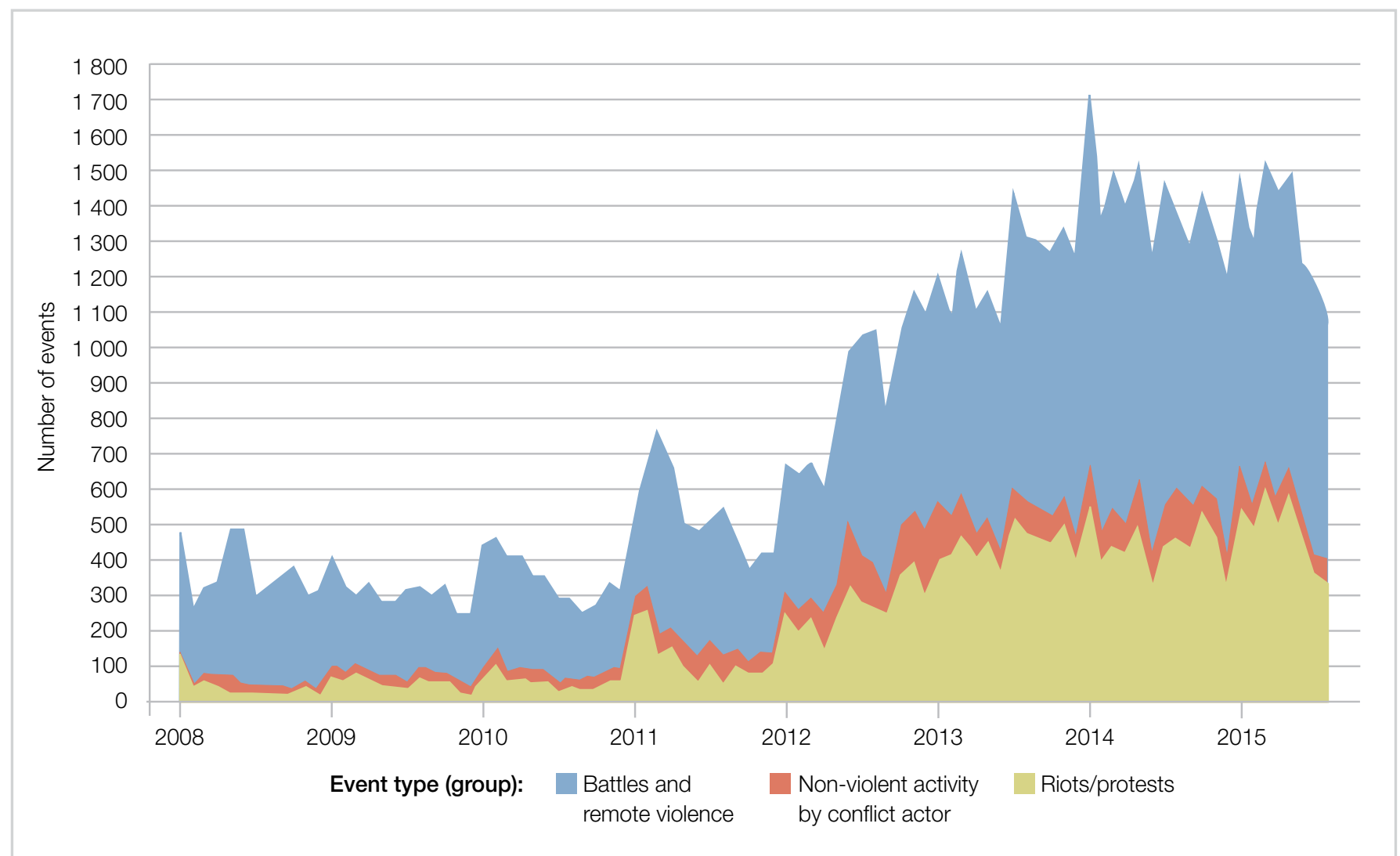

Source: ACLED. Version 5, All Africa 1997 - 2014, www.acleddata.com/data/version-5-data-1997-2014, updated with Realtime data to 3 September 2015, www.acleddata.com/data/realtime-data-2015 (accessed 13 September 2015). ACLED gathers data in nine event types that have been collapsed into three event types in this figure. 
as Nigeria (largely because of the activities of Boko Haram) and Somalia (because of al-Shabaab's campaign), and were largely unrelated to the increase in politically violent events. Almost 37\% of the 39286 fatalities recorded by ACLED in Africa in 2014 occurred in Nigeria. Although there were almost as many incidents of riots and protests as battles or violent activities against civilians, the fatality rate per event for riots and protests was considerably lower.

Riots and protests occurred throughout the continent but the greatest number in 2014 took place in Egypt, South Africa, Nigeria, Libya and Kenya, in that order.

In summary, different datasets confirm that the period from 2005 to 2010 can generally be seen as relatively stable (by recent historical standards) with subsequent increases in both the total number of conflict/politically related events and associated fatalities thereafter but in different countries and for different reasons.

Figure 5 uses the same dataset that was used for Figure 4 and now maps the events geospatially using different colours for types of events and bubble size to represent the number of fatalities.

Figure 5: Politically violent events in Africa from January 2008 - August 2015

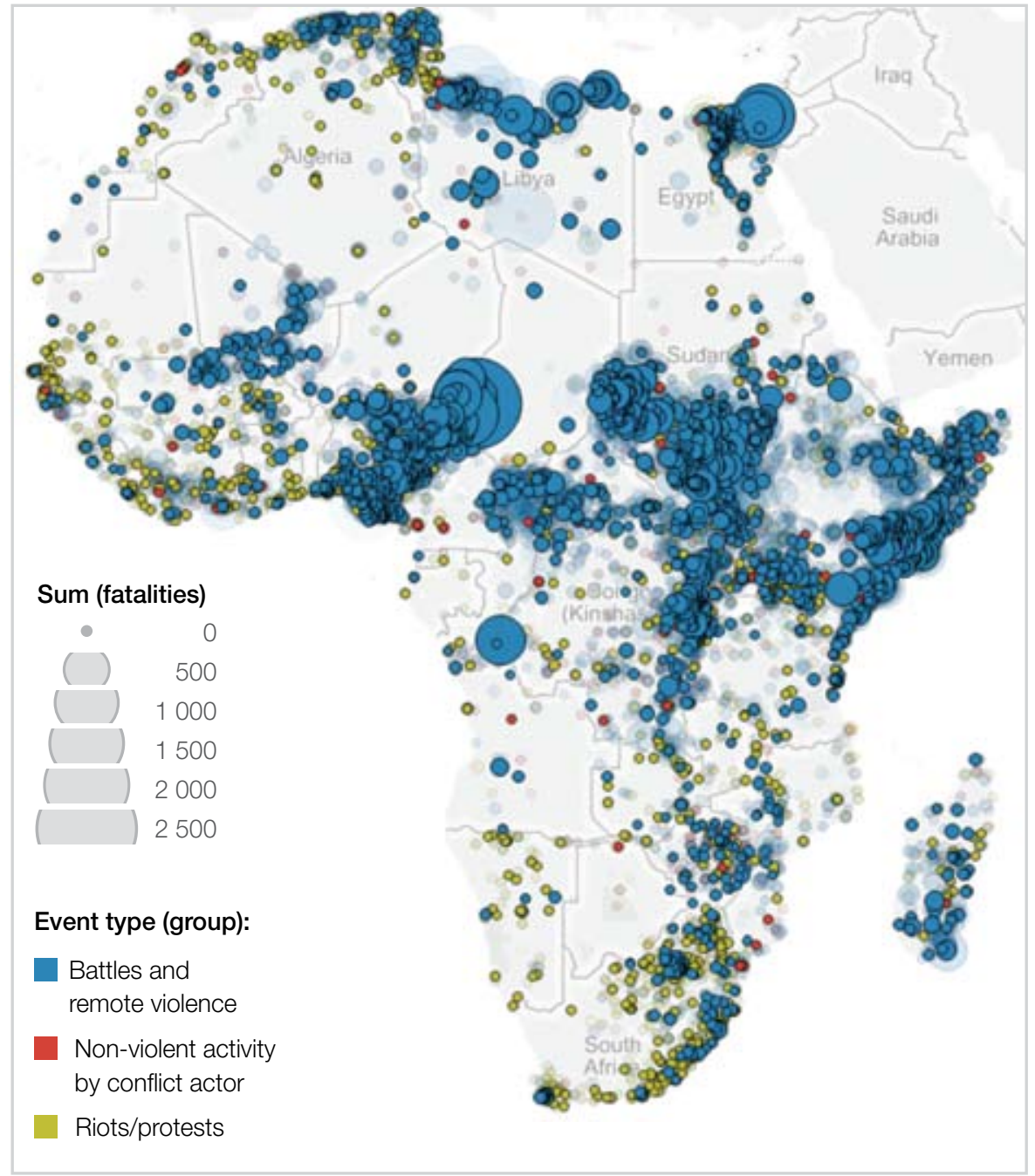

Source: ACLED version 5, All Africa 1997 - 2014, wnw.acleddata.com/data/version-5-data-1997-2014 updated with Realtime data to 3 September 2015, wnw.acleddata.com/data/realtime-data-2015 (both accessed 13 September 2015). ACLED gathers data in nine event types that have been collapsed into three event types in this figure.

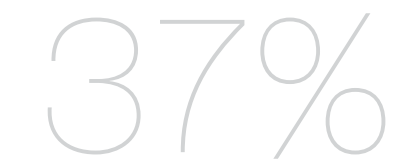

OF FATALITIES RECORDED

IN AFRICA IN 2014

OCCURRED IN NIGERIA 


\section{The fatality burden at country level}

Above I commented on the importance of population size when considering the fatality burden of Africa compared to other regions. The same principle should apply when comparing the fatality burden at national level between countries with large differences in population size and suffering from very different levels of political violence.

According to ACLED, the nine countries that had the highest number of fatalities in 2014 were Nigeria, South Sudan, Somalia, Sudan, the CAR, Libya, Egypt, Cameroon and the $\mathrm{DRC}$, in declining order of magnitude (see Figure 6a). Collectively these countries contributed $92 \%$ of the total fatalities recorded by ACLED in that year. But they have vastly different population sizes, ranging from Nigeria with an estimated population of 178 million to the CAR with a population of less than 5 million, which is a 38 times smaller population than Nigeria's. As a result, the fatality burden differs markedly between them. Even though Somalia only has an estimated 11 million people, it had almost half the fatalities of those recorded for Nigeria, which has 16 times more people than Somalia.

\section{While Africa has very high levels of instability on a global level, the vast number of fatalities occur in quite a small number of countries}

As reflected in Figure 6b, the fatality burden from political violence per 100000 population is highest in four countries, namely the CAR, South Sudan, Libya and Somalia. Most remarkable is Nigeria's shift from the most violent to the sixth most violent country. Even more important is the only $8 \%$ of fatalities occurred in the remaining 42 countries for which ACLED gathers data in Africa. While Africa has very high levels of instability on a global level, the overwhelming number of fatalities occurs in quite a small number of countries.

Figures 6a and 6b: Total fatalities vs fatalities per 100000 people (2014)

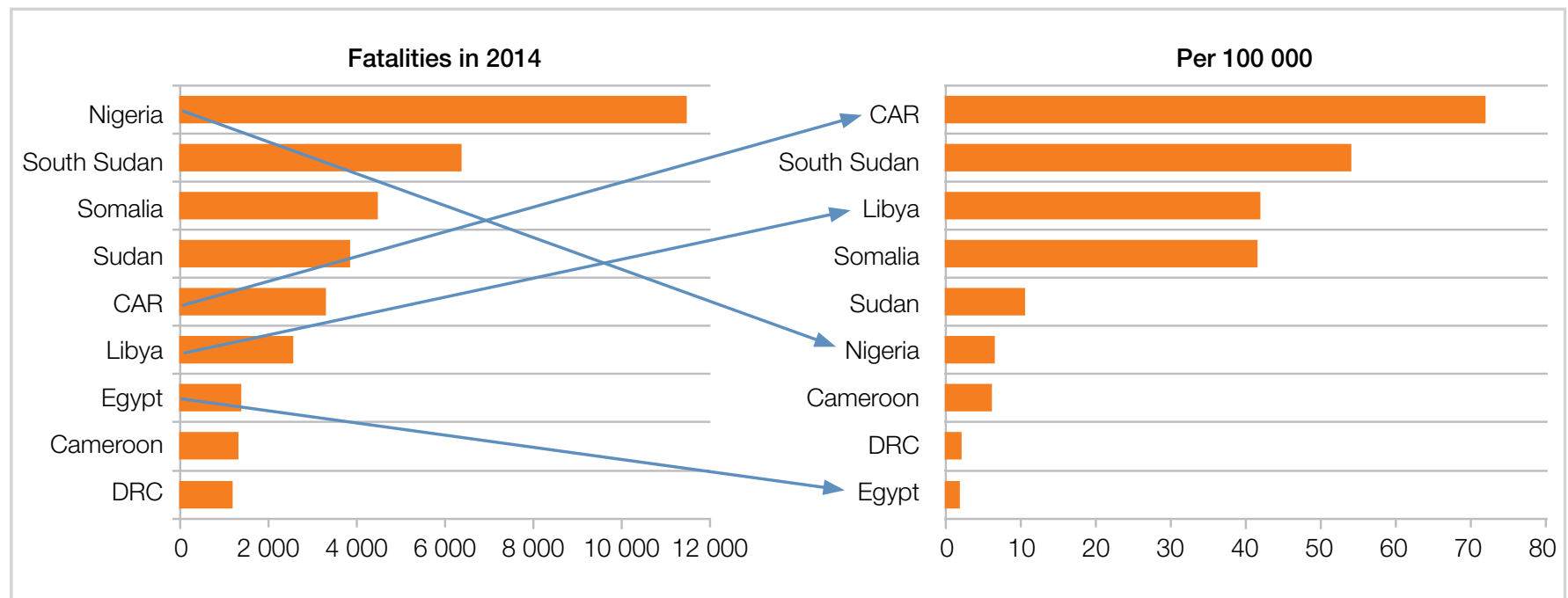

Source: Computed from ACLED version 5, All Africa 1997 - 2014, http://wnw.acleddata.com/data/ version-5-data-1997-2014 (accessed 13 September 2015). 
Figure 7: The world and Africa: Fatalities from non-state armed conflict vs population size

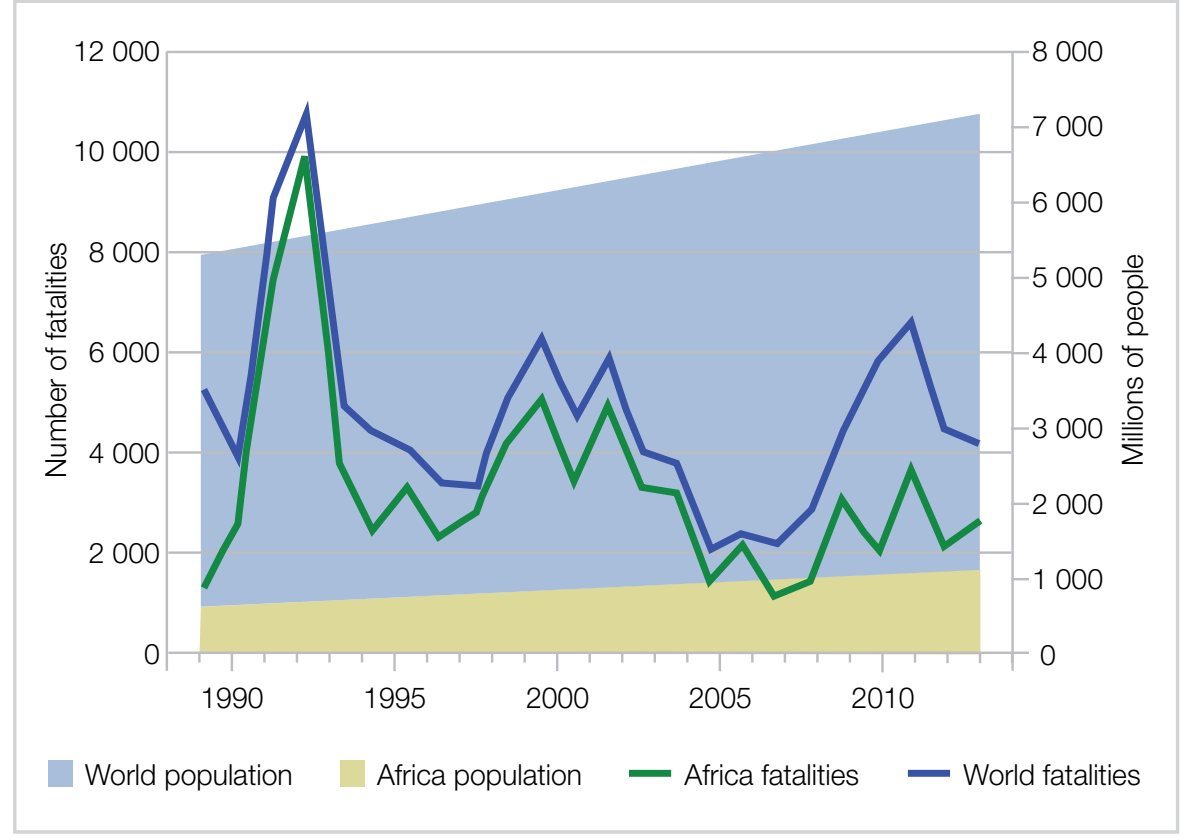

Source: UCDP Non-State Conflict Dataset, v.2.5-2014, 1989 - 2013, www.pcr.uu.se/research/ucdp/ datasets/ucdp_non-state_conflict_dataset (accessed 10 July 2015). UNDP population data from IFs version 7.09.

\section{Non-state violence in Africa}

For several decades Africa and the Middle East have been the global regions with the highest armed conflict burden when measured relative to population size. ${ }^{15}$ Different to other regions, Africa and the Middle East also evidence a high level of so-called 'nonstate conflict', i.e. conflicts between various armed groups and factions fighting one another and not the government. The number of conflict actors has steadily increased in recent years. ${ }^{16}$ The traditional pattern of governments fighting rebels has given way to a complex tapestry within which rebel movements split and fight one another, and sometimes the government as well. They generally do so on the periphery of states and seldom threaten central state control in capitals, although there are notable exceptions, as with Mali, the CAR and Libya, amongst others. ${ }^{17}$

The UCDP defines non-state conflict as 'the use of armed force between two organised armed groups, neither of which is the government, which results in at least 25 battle-related deaths in a year'. ${ }^{18}$ The number of such events and the associated fatalities are consistently higher for Africa than for any other region globally. Figure 7 reflects this trend: the global levels of fatalities from non-state conflict (left-hand scale), which closely track those from Africa since 1990, are significantly higher, on a proportional basis, than the relative size of Africa's population compared to the global population (right-hand scale).

The intensity of non-state conflict in Africa has peaked twice in recent history, between 1991 and 1994, primarily as a result of conflict in the Eastern DRC, Sudan and Somalia, and the genocide in Rwanda, and from 1998 to 2004, mainly because of conflict in the Eastern DRC and Nigeria. The rise in global fatalities from 2009 to 2011 is largely the result of fatalities from organised crime in Mexico and fatalities in Sudan, South Sudan and Nigeria.

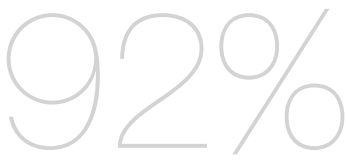

OF TOTAL FATALITIES RECORDED IN 2014 OCCURRED IN ONLY NINE COUNTRIES 


\section{The imbalances that drive instability}

In a 2013 ISS paper entitled The future of intrastate conflict in Africa: More violence or greater peace?, the authors discussed seven structural correlations associated with intrastate armed conflict in Africa and concluded that:

Violent armed conflict and resource insecurity will continue to occur mainly in poor countries where the following variables are present: weak governance, previous experience of conflict, spill-over from being located in a bad 'neighbourhood', and/ or widespread youth unemployment and exclusion co-existing alongside a median age of below 25 years. ${ }^{19}$

The paper expanded on this theme and modelled the impact of various conflict scenarios on Africa's population size, growth, development prospects and poverty alleviation.

Explanations for instability obviously differ from country to country but statistically the largest indicator of future conflict is past conflict. ${ }^{20}$ Breaking the conflict trap is exceptionally difficult and once a country has experienced large-scale internal conflict, such as currently the case with Sudan, South Sudan, the CAR, Nigeria, Somalia and the $\mathrm{DRC}$, only an extraordinary large effort, often with the assistance of the international community through comprehensive peacekeeping or peacebuilding efforts, is able to break that cycle. Some countries with a long history of conflict do make progress, such as Ethiopia, Rwanda, Angola, Mozambique and Sierra Leone, but stability often remains fragile with the constant chance of reversal.

\section{Regime type and the multiplier effect of limited governance could be important explanatory factors when considering Africa's relatively high conflict burden}

At a regional level of analysis, regime type and the multiplier effect of limited or thin governance appear to be important explanatory factors when considering Africa's relatively high conflict burden.

In 2014, Barry Hughes and others of the Frederick S. Pardee Center for International Futures, University of Denver, set out a comprehensive framework to model and forecast three complementary dimensions of governance, namely security, capacity and inclusion, using the International Futures forecasting system (IFs). ${ }^{21}$ Exact modelling is complex and beyond the scope of this paper, but the authors sought to build upon the substantial body of literature that had set out to understand the process of state formation. They saw the processes of security, capacity and inclusion as three broad but essentially sequential transformations in that process.

Generally, a government's capacity to ensure law and order, police its territory effectively, monitor borders and suppress dissent is the most important determinant of stability, or the lack thereof. The majority of African governments do not fully control their territory, are unable to police their borders and, in extreme cases such as the DRC or Mali, may be battling rebel groups that effectively control some of its provinces. In these circumstances external actors and events have a greater impact upon domestic stability than would otherwise be the case. Thus, relatively insignificant events such as the actions of a large multinational corporation pursuing commercial advantage, or a riot could have an impact vastly out of proportion to its original intention or scope. 
The level of armed conflict in Africa is therefore quite sensitive to external developments, including global competition and fluctuations in commodity prices.

Building on the analysis presented in previous ISS papers on conflict trends and the dimensions of governance by Hughes and others, two distinct types of systemic imbalance appear to explain the high levels of violence in the MENA and sub-Saharan Africa regions. In the latter, instability is largely driven by the lack of capacity to govern, while the MENA region has particularly low levels of political and economic inclusion. This is represented graphically in Figs 8 and 9, and briefly explained below.

Capacity is generally defined as the mobilisation and effective use of revenue. Amongst others, Hughes' study draws upon the tendency of modern states 'to mobilise and use a progressively higher share of gross domestic product as they develop economically and build professional public administrations'. ${ }^{22}$ Leaving the exact formulation of the index aside, Figure 8 presents the governance capacity index for sub-Saharan Africa compared to the Middle East, North Africa and the average for the world in 2011 (the year when the Arab Spring started in Tunisia), using IFs. It is clear that the sub-Saharan region has significantly less governance capacity than the Middle East and North Africa. In fact, it is significantly below the world average.

In Africa, governance capacity is highest in North Africa and Southern Africa, not an unexpected finding given the relatively high levels of income of these regions compared to the rest of Africa. The lowest capacity is found in Central and West Africa, with East Africa and the larger Horn region doing slightly better.

The lack of state capacity is particularly evident in fragile states affected by conflict, such as Chad, Sudan, South Sudan, Nigeria, the CAR, Sierra Leone, Mali and the $\mathrm{DRC}$. The capacity deficit reflects the incomplete process of state formation in these countries. ${ }^{23}$ Central governments do not have control over their territories, their legitimacy is contested, the borders are not under their control, little tax is levied and only limited services are provided - and they do not generally have the capacity to undertake much of this.

Figure 8: Sub-Saharan Africa's governance capacity deficit

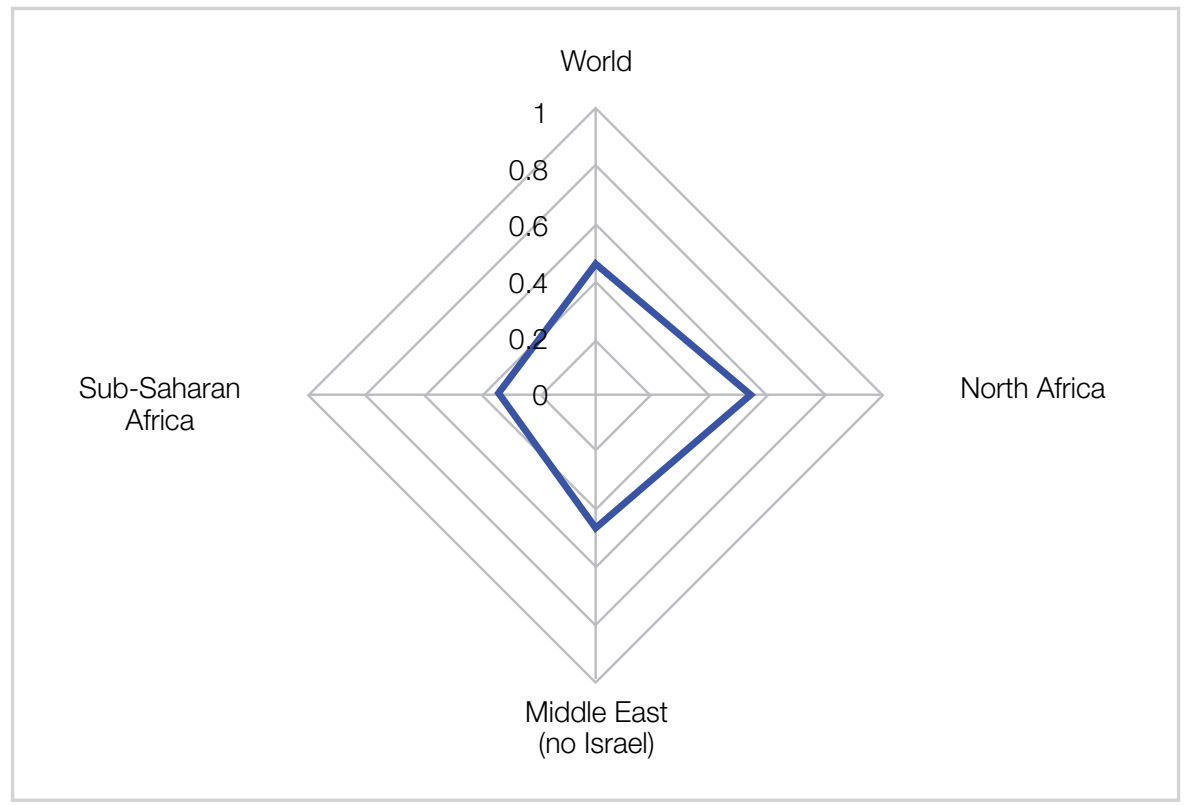

Source: International Futures v7.15. 
Inclusion relates to the extent of participation associated with society in the broad political processes and government itself. ${ }^{24}$ To model inclusion, Hughes and his collaborators considered a range of measures of regime-type and gender empowerment. 'The global progression of democracy relative to autocracy is the fundamental element of the inclusion transition.' ${ }^{25}$ To a degree, progress with inclusion requires minimum security and capacity, and reflects additional progress along the state-formation process. In 2011, inclusion levels were particularly low in the Republic of Congo, Morocco, Swaziland, Tunisia, Mauritania, Eritrea, amongst others.

The results from modelling the levels of inclusion is presented in Figure 9, which indicates the extent to which the MENA region generally suffers from poor political and economic inclusion. This aspect is, in fact, significantly below the levels found in sub-Saharan Africa and the world on average. At the same time, that region is extraordinarily richly endowed with natural resources, oil and gas, in particular, and is therefore a region with the potential to provide services and opportunities on a broad basis to its peoples.

Figure 9: The MENA governance inclusion deficit

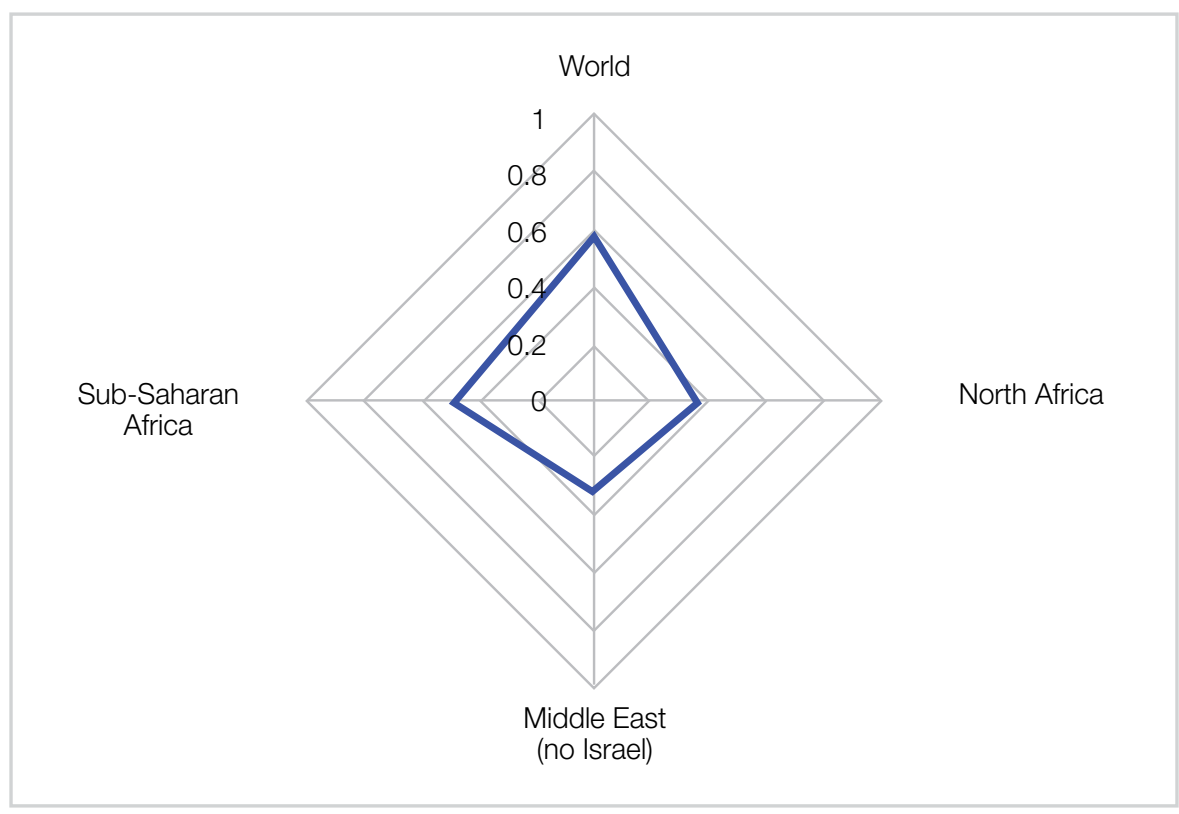

Source: International Futures v7.15.

While average income levels grew much more rapidly in the Middle East and in North Africa than in sub-Saharan Africa, political inclusion changed only marginally until the events of the Arab Spring changed the average score for North Africa, with Tunisia showing the largest improvement. This change occurred the same time as education-level improvements slowed down in sub-Saharan Africa. The sum impact was a larger increase in relative deprivation (the political awareness of absolute deprivation) in North Africa and the Middle East compared to sub-Saharan Africa. North Africa therefore suffers from a large democratic deficit, and the Middle East even more so. Both the conclusions are evident in Figure 9.

Most African governments are of a mixed regime type (so-called anocracies), displaying both democratic and autocratic characteristics. Anocracies are inherently less stable than either autocracies (the most stable form of regime) or full multiparty democracies. The ongoing process of democratisation in Africa inevitably increases 
Figure 10: Summary of regime characteristics over time

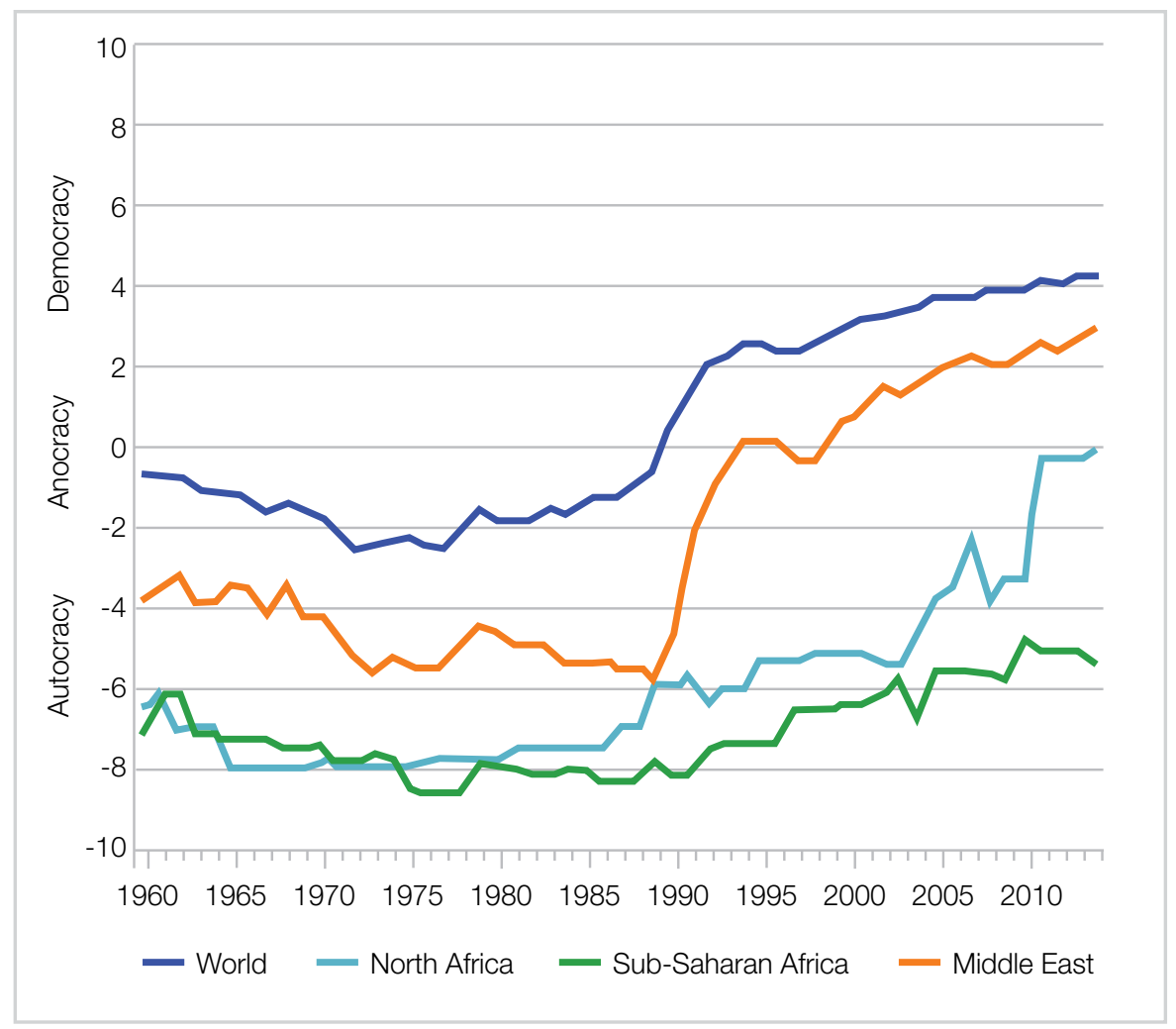

Source: Policy IV data to 2014 available on the website of the Centre for Systemic Peace, www.systemicpeace.org/inscrdata.html (accessed 15 August 2015).

instability. An examination of democratisation trends (Figure 10) using data from the Polity IV dataset ${ }^{26}$ shows that levels of democracy in sub-Saharan Africa were steadily deteriorating until the end of the Cold War. They then improved substantially during the between 1989 and 1994, only to be followed by slower rates of improvement thereafter. With the exception of countries such as Swaziland, Eritrea and Equatorial Guinea, the levels of democracy in sub-Saharan Africa are significantly higher than those in North Africa, having improved steadily over time.

Improvements in the levels of democracy in North Africa only occurred as pressure from the Arab Spring forced change in Tunisia, but led to disastrous consequences in adjoining Libya. ${ }^{27}$ Average levels of democracy in the Middle East are even lower than in North Africa. The region only very recently graduated from full autocracy.

This incongruence between relatively high levels of human development on the one hand and very low levels of political voice and accountability, or inclusion, on the other go a long way towards explaining the rupture now known as the Arab Spring, with all its unforeseen consequences. It also points to the inevitability of continued high levels of instability in the Middle East, despite the ability of countries such as Saudi Arabia, the UAE, Kuwait and Qatar to buy off the demands for greater inclusion by offering non-political concessions based upon their oil income. In effect, the MENA region appears to be trapped. Generally, its regime types have an unstable mixture of autocratic and democratic characteristics and are all therefore categorised as anocracies in the polity classification system. In these circumstances relative deprivation is exceptionally high, and economic growth and rising expectations will inevitably have a huge impact on the prospects for stability as oil income declines.

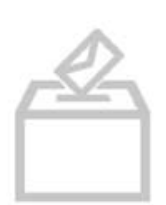

LEVELS OF DEMOCRACY IN SUB-SAHARAN AFRICA ARE SIGNIFICANTLY HIGHER THAN IN NORTH AFRICA 
The differences in inclusion also manifest themselves in different ways in Arab Muslim countries in North Africa when compared with communities in the rest of Africa. A shared history and religion is one part of this picture in which the capacity gaps within Arab Muslim societies in North Africa create a vacuum that is frequently filled by grassroots Islamic organisations (such as the Muslim Brotherhood). They step in to provide goods and services in health, education and housing. In the process, the strength of these Islamic networks magnify the weakness of the state system and opens up the field for the rise of radical Islam with its own political agendas. ${ }^{28}$ This situation is not replicated elsewhere in the continent and the ethos of Muslim charity and help across boundaries appears to be much stronger in Arab Muslim societies than in regions that do not share this overarching influence.

\section{Contextualising violent Islamist extremism}

Definitions of terrorism have always been contentious in Africa for two reasons. In a number of countries ranging from Algeria to South Africa, groups that were designated terrorist by a number of Western governments later became liberation movements and, shortly thereafter, governments. Another reason is that it is often difficult to draw a reasonable distinction between the actions of sub-state organisations such as the Lord Resistance Army (Uganda/Eastern DRC), the Forces démocratiques de libération du Rwanda (Eastern DRC), the Mai Mai (Eastern DRC), and Balaika and Séléka (the CAR), and 'accepted' terrorist organisations such as al-Shabaab (Somalia). As a result, the coding/classification of terrorist incidents is fraught with political and practical challenges. Even more problematic is labelling organisations (instead of acts) as inherently terrorist in terms of amelioration strategies. ${ }^{29}$ For these reasons the Organisation of African Unity (OAU) and its successor, the African Union (AU), have adopted a complex definition of terrorism that notes that 'the struggle waged by peoples in accordance with the principles of international law for their liberation or selfdetermination, including armed struggle against colonialism, occupation, aggression and domination by foreign forces shall not be considered as terrorist acts. ${ }^{30}$

\section{The capacity gaps within Arab Muslim societies create a vacuum that is often filled by grassroots organisations}

An explanation of causality and evolution when dealing with violent political extremism (as with other social phenomena) is inherently controversial and inevitably incomplete. By way of example, the long-standing African scholar Roland Marchal presents a useful summary of the different interpretations that feed into understanding the motivations behind an organisation such as Boko Haram (now calling itself the Islamic State's West Africa Province) in Nigeria:

Firstly, it refers to the long history of the region and the recurrence of radical Islamic movements. Secondly, Boko Haram has deep roots in the social and economic marginalisation of a large section of the northern states' population. A third understanding of Boko Haram emphasises the revenge dimension and questions the behaviour of the law enforcement agencies, their poor respect for the rule of law and the militarisation of any response to challenges to the central state. The fourth vision sees Boko Haram as a tool used by northern Nigerian 
elites to express their grievances against the lack of interest showed by the central state. Lastly, because of its developing connections with al-Qaeda in the Islamic Maghreb and possibly al-Shabaab, Boko Haram is changing the scope of its grievances and providing the ground for a lasting confrontation between radicalised Muslims and others in Africa. ${ }^{31}$

While Boko Haram has killed thousands of Nigerians, a report on Bloomberg Business placed things in stark perspective by noting that the lack of running water has probably killed more people in Nigeria in 2014 than Boko Haram..$^{32}$ Ethnicity also plays a role as most of the members of Boko Haram belong to the ethnic Kanuri, who once ruled over an empire founded in the modern-day province of Borno, but today are largely unemployed and illiterate with little or no schooling. ${ }^{33}$

\section{When the mosque is the only outlet for mass politics, the outcome is predictable: the Islamisation of dissent}

Ömer Taspınar provides an insightful analysis of the relationship between relative deprivation and radicalisation in the Arab world, including North Africa. After pointing to the degree to which globalisation exacerbates frustration, victimisation and humiliation among growing cohorts of urbanised, undereducated and unemployed Muslim youth, he points to the extent to which Muslims of both genders are caught in the growing tension between religious tradition and western modernity. Furthermore:

Socioeconomic decay in the Islamic world often creates considerably more frustration than in other parts of the developing world for historical reasons, as well. Particularly in the Arab world, a sense of nostalgia for the golden age of Islam -during which Arab civilisations far surpassed Europe - is deeply ingrained in the political culture. Unlike other developing regions of the world, Arab countries have a historic, cultural and civilisational sense of rivalry with the Christian West. Geographic proximity further complicates this picture. Europe is often a historic point of reference in terms of social, economic and political success. Feelings of a historic sense of superiority combined with the more recent memories of colonial subjugation and military defeat create a dangerous sense of victimisation, resentment and injustice in large parts of the Arab world. All these factors significantly compound the level of frustration of a great civilisation nurturing great expectations and aspirations. ${ }^{34}$

The absence of opportunity and voice brings a political dimension to relative deprivation in the MENA region as the gap between political aspirations and the realities on the ground has grown. 'In most authoritarian Muslim countries, the mosque is the only institution not brutally suppressed by the regime. And when the mosque is the only outlet for mass politics, the outcome is predictable: the Islamisation of dissent. As dissent turns Islamic, what naturally follows is the politicisation of Islam'. ${ }^{35}$ The result is the growth of radicalisation and, sometimes, of extremist violence.

In recent history, the key events that have driven the larger increases in violent Islamist extremism globally can be set out in three broad cycles. The first cycle started with the 11 September 2001 attacks on the USA (9/11) that lead to the war in Afghanistan shortly thereafter and eventually to a steady attrition of the ability of al-Qaeda to

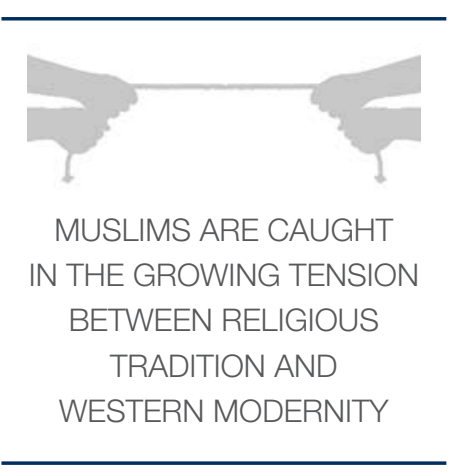


pursue international terrorism. The second cycle started with the US-led invasion of Iraq in March 2003. The invasion of Iraq breathed new life into global terror with the formation of al-Qaeda in Iraq in November 2004. This movement eventually morphed into the Islamic State that now controls large parts of Iraq and Syria. The Arab Spring that started in Tunisia in December 2010 kicks off a third and overlapping cycle that feeds into the previous two cycles.

Subsequent mass mobilisation rapidly spreads to other countries, to Egypt and Libya in particular - countries that shared the same repression, corruption and potential for violent radicalism as Tunisia. Apart from revolutionary change in these three countries, the fall-out from the Arab Spring also leads to a change in government in Yemen. Civil uprisings erupted in Bahrain and Syria, and protests broke out in Algeria, Iraq, Jordan, Kuwait, Morocco and Sudan. Minor protests occurred in Mauritania, Oman, Saudi Arabia, Djibouti, Western Sahara and Palestine.

\section{Domestic counter-terrorism measures adopted by Egypt and elsewhere may have set political and economic liberalisation in north Africa back several years}

When looking back five years later, the impact of the Arab Spring was largely to weaken authoritarian control in the affected countries. However, the momentum was insufficient to facilitate a legitimate and effective replacement of government. The uprising's most spectacular and destabilising episode was the ousting of Muammar Gaddafi in 2011, which spread Tuareg mercenaries, weapons and supplies across the Sahel, leading to the establishment of the short-lived Islamic Republic of Azawad in northern Mali. It opened up a jihadist space in the Sahel between Mauritania, Algeria, Tunisia and Libya.

In Syria, President Bashar al-Assad has been able to withstand the impact of the Arab Spring, but has lost control over large parts of his country since then. The withdrawal of US forces from neighbouring Iraq facilitated the rise of the Islamic State to its current pre-eminence over al-Qaeda.

Eventually the blowback of the War on Terror (the invasion of Iraq in particular), the regional impact of the collapse of central state control in Libya and the domestic counter-terrorism measures adopted by the current government in Egypt and elsewhere may have set political and economic liberalisation in North Africa back several years.

Perceptions of risk are highly correlated with levels of news coverage, but may be quite different from actual risk. ${ }^{36}$ The current impression, considering the extent of news coverage, is that terrorism is a large contributor to instability and to fatalities in Africa, particularly in those countries with high levels of conflict.

\section{Sizing the terrorism problem}

Figure 11 draws on data from the Global Terrorism Database (GTD) ${ }^{37}$ to present terrorism globally and in Africa. It shows a sharp rise in the global occurrence of terrorism (i.e. the number of events) since 2004, reaching a plateau between 2008 
Figure 11: Terrorist incidents globally and in Africa from 1989 - 2014

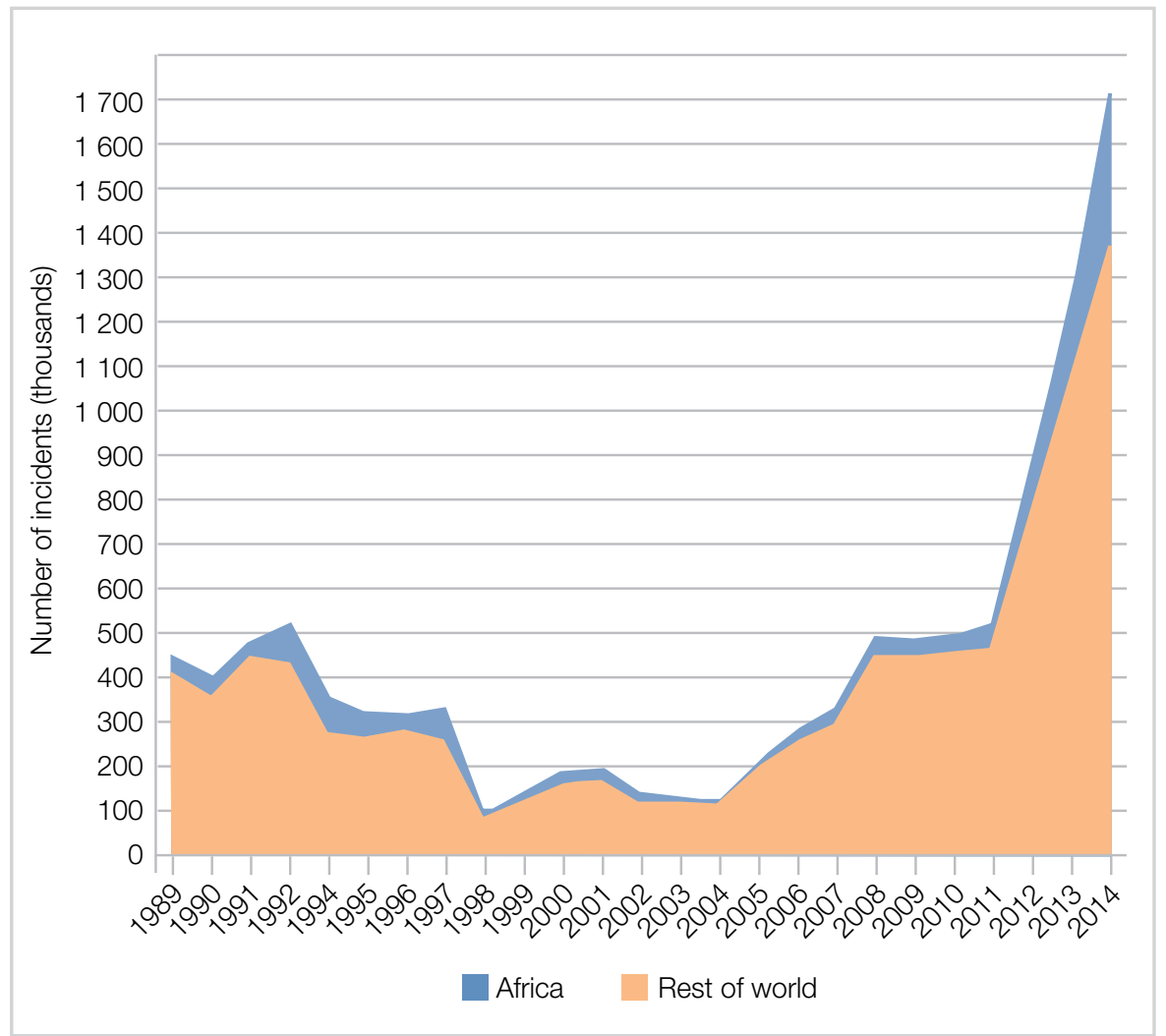

Source: Extract from GTD 1970 to 2014, National Consortium for the Study of Terrorism and Responses to Terrorism, University of Maryland, www.start.umd.edu/gtd (accessed 3 July 2015). Note that data for 1993 is not available.

and 2011, but accelerating sharply in 2011 and 2012 after the US-led invasion of Iraq. The GTD data also indicates that fatalities from terrorism in Africa increased steeply in 2014. One third of the 43512 fatalities from terrorism recorded by the GTD for that year occurred in Africa. This is largely the result of the extraordinary high levels of violence perpetrated by Boko Haram in Nigeria. Figure 12 reflects these three cycles: steady decline in terrorism globally to 2004 and then a sharp acceleration from 2011.

Figure 12 presents the total number of fatalities (victims and attackers) from terrorism in Algeria, Egypt, Libya, Nigeria and Somalia from 1995 to 2014. Terrorism in Algeria reduced to nominal levels by 2011 but it expanded exponentially in Nigeria. Also evident is the growth of terrorism in Somalia from 2006, with a sharp increase from 2011. Without the impact of Boko Haram, fatalities from terrorism in Africa would have remained at a relatively constant level in the last two decades.

But what is the contribution of Islamist terrorism to terrorism? Figure 13 displays the total fatalities on both sides from political violence in Algeria, Egypt, Libya,

Mali, Nigeria, Tunisia and Somalia, the countries in Africa most affected by Islamist terrorism. During the five-year period from 2010 to 2014, ACLED data indicates that a total of 71433 people died from political violence. Of these $24 \%$ died as a result of Islamist terror groups. ${ }^{38}$ The trend line indicates that Islamist terror is growing, but at a slower rate than fatalities from political violence as a whole. The spikes in 2011 and 2014 were the result of events in Libya (where only a small amount of events are the result of terrorism) and Boko Haram in Nigeria, respectively.

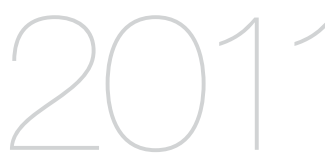

TERRORISM INCREASES SHARPLY IN SOMALIA 
Figure 14 is the counterpart to Figure 5. It now only presents violence associated with the most prominent violent Islamist extremist organisations in each of the most affected countries. A comparison of these two maps will provide an indication of the relative contribution of Islamist terror in Africa.

Figure 12: Fatalities from terrorism in the five most affected African countries, $1995-2014$

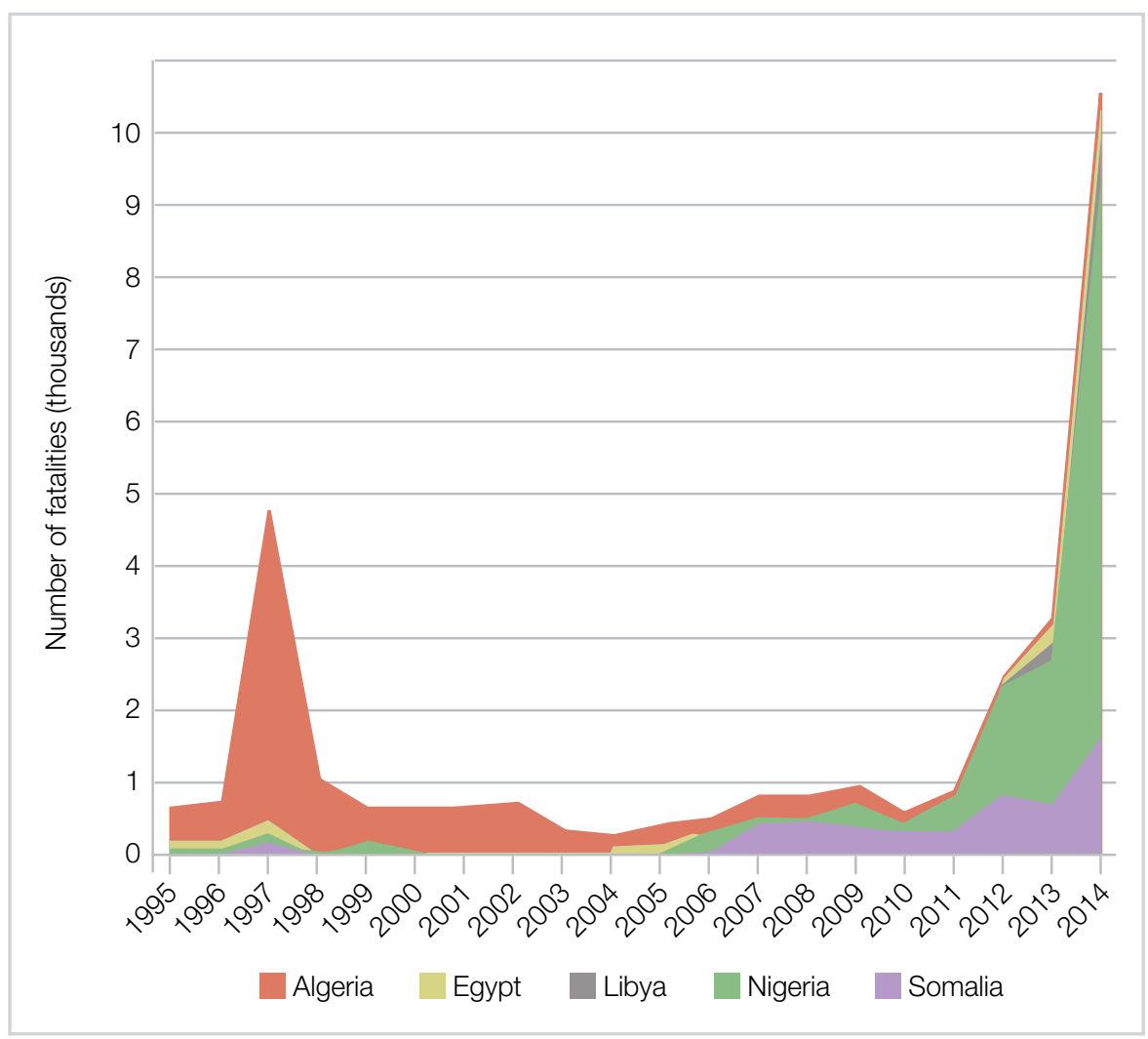

Source: GTD 1970 to 2014, National Consortium for the Study of Terrorism and Responses to Terrorism, University of Maryland, www.start.umd.edu/gtd (accessed 3 Sep 2015).

Figure 13: Total fatalities from political violence vs fatalities from Islamist terrorism in selected African countries 2010 - 2014

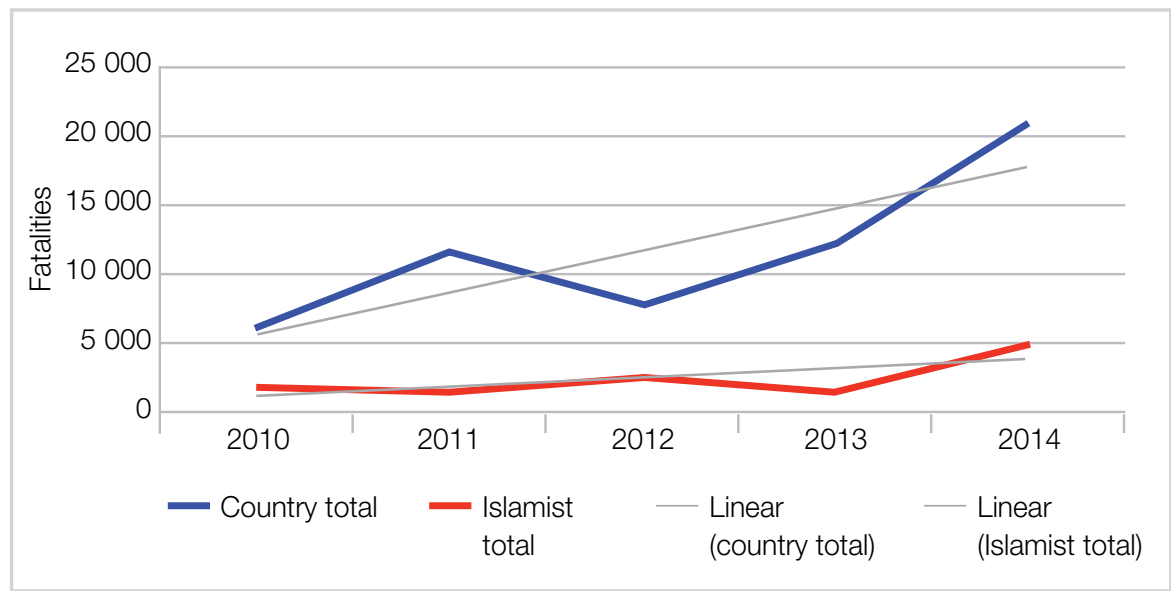

Source: Extract from ACLED version 5, All Africa 1997 - 2014, www.acleddata.com/data/version-5data-1997-2014 (accessed 14 July 2015). 
Figure 14: Violent jihadi activities in Africa from January 2008 - August 2015

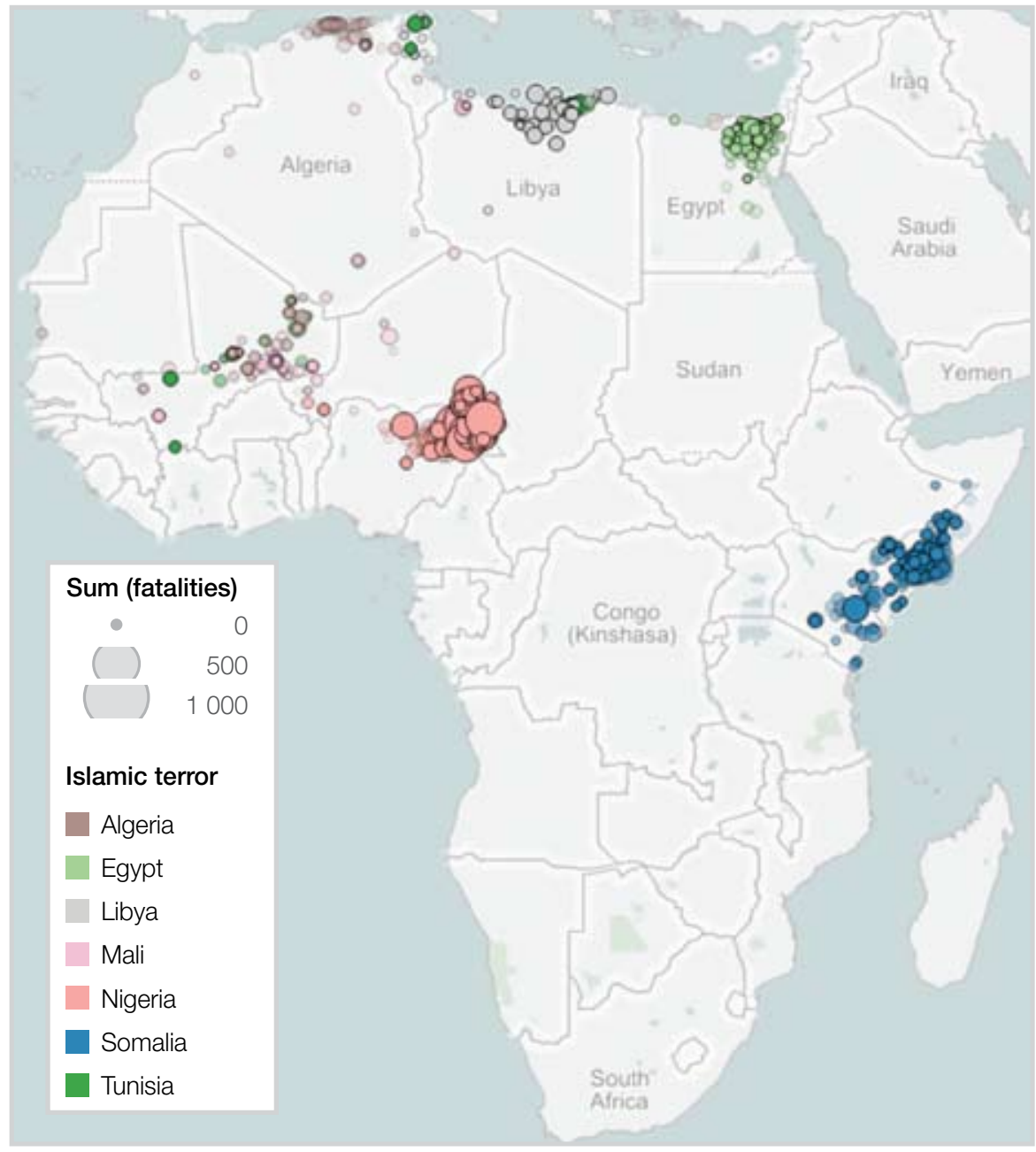

Source: ACLED version 5, All Africa 1997 - 2014, www.acleddata.com/data/version-5-data-1997-2014 updated with Realtime data to 3 September 2015, www.acleddata.com/data/realtime-data-2015 (both accessed 13 September 2015). ACLED gathers data in nine event types that have been collapsed into three event types in this figure.

\section{Conclusion}

The analysis presented in this paper builds on previous papers from the ISS that reviewed the drivers, trends and characteristics of violence in Africa.

Using data from three sources, namely the UCDP, ACLED and the GTD, this paper presents a story of a rapid increase in armed conflict and violence in the decade preceding the collapse of the Berlin Wall, and an even more rapid decline thereafter to levels approximating those several decades earlier. Previous work has already pointed to the fact that Africa and the Middle East are the two regions that have the highest conflict burden in the world when fatalities are measured in proportion to population size. Beyond their high levels of armed violence, the two regions share a second characteristic in that both have particularly high levels of non-state violence, i.e. conflict that does not involve government.

From 1989, terrorism in Africa constituted a relatively small component of global terrorist activity (as measured by the GTD). This changed in 2011 with the impact of events in Nigeria owing to the extraordinary brutality and widespread murder by Boko Haram. This pushed up Africa's terrorist fatalities considerably.

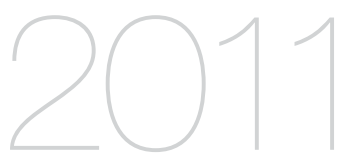

AFRICA'S TERRORIST FATALITIES ARE PUSHED UP CONSIDERABLY BY BOKO HARAM 
In those countries most affected by violent Islamist extremism, about one quarter of total fatalities can be ascribed to those organisations generally associated with terrorism. Other types of political violence such as riots, violence against civilians and the like has been responsible for far more incidents and higher levels of casualties than extremist Islamist violence. Thus, while Islamist terror is increasing in Africa, even if at rates well below those in the Middle East, other types of political violence have increased more rapidly. The relative contribution of terrorism to that increase is important but less steep.

\section{Africa and the Middle East are the two regions that have the highest conflict burden in the world when fatalities are measured in proportion to population size}

This conclusion should not detract from the threat from extreme Islamist violence, or for the need to combat its nefarious impact, particularly in key affected countries such as Nigeria, Somalia, Algeria, Tunisia, Libya and Egypt. It is clear that the threat from al-Qaeda and the Islamic State has spread to Africa in a concerted and meaningful way (that is an issue to be explored in greater depth in a follow-on ISS paper). Local movements align themselves to the Islamic State or al-Qaeda as part of their efforts to increase their reach and influence. There is thus a bandwagon effect that is dependent on the success of the Islamic State vs al-Qaeda brand. But it is also important to place the threat from extreme Islamist violence in Africa in its appropriate relative context.

Eventually the central challenge for sub-Saharan Africa is to build accountable, capable governments that are able to deliver security and inclusive growth. Africa seems to be making steady if halting progress in this regard. Daunting as this challenge may be, it pales in comparison to the challenge of broadening representation in the Middle East where the toxic mixture of competing religious groups and governments clash with the desire by small elites, such as in Saudi Arabia, to control political power and wealth. 


\section{Notes}

1 Jakkie Cilliers and Julia Schünemann, The future of intrastate conflict in Africa: More violence or greater peace? ISS paper no. 246, May 2013: 16, www.issafrica.org/publications/papers/the-futureof-intrastate-conflict-in-africa-more-violence-or-greater-peace; Jakkie Cilliers and Steve Hedden, Africa's current and future stability, ISS paper no 274, 20 November 2014, www.issafrica.org/ publications/papers/africas-current-and-future-stability; Jakkie Cilliers, Africa's conflict burden in a global context, ISS paper no 273, 22 October 2014, www.issafrica.org/publications/papers/africasconflict-burden-in-a-global-context (all accessed on 10 September 2015).

2 The Uppsala Conflict Data Program (UCDP) collects and publishes a large number of conflict datasets. See www.pcr.uu.se/research/ucdp/datasets. Those used in this publication are the UCDP/ PRIO Armed Conflict Dataset v. 4-2015, 1946-2014, and the UCDP Non-State Conflict Dataset v. 2.5-2014, 1989-2013.

3 The Armed Conflict Location and Event Data Project (ACLED) collects and codes event data on conflict and political events on a two-weekly basis, and includes political violence and protests by governments, rebels, militias, communal groups, political parties, rioters, protestors and civilians. The ACLED datasets used in this paper are ACLED Version 5 (1997-2014) standard, and 2015 Real-time Data updated to 3 September 2015

4 The Global Terrorism Database (GTD) is maintained by the National Consortium for the Study of Terrorism and Responses to Terrorism (START). See www.start.umd.edu/gtd. The GTD dataset used in this paper is the GTD 1970-2014 data file.

5 Sub-Sahara Africa includes all African countries except those countries listed as part of North Africa.

6 North Africa consists of Algeria, Egypt, Libya, Mauritania, Morocco and Tunisia.

7 The Middle East consists of Bahrain, Iran, Iraq, Jordan, Lebanon, Kuwait, Oman, Qatar, Saudi Arabia, Syria, UAE and Yemen.

8 Steven Pinker, The Better Angels of our Nature, New York, Viking, 2011.

9 Andrew Mack (ed.), Human security report 2013 - The decline in global violence: evidence, explanation and contestation, Simon Fraser University, Vancouver, www.hsrgroup.org/humansecurity-reports/2013/text.aspx: 2 (accessed 6 August 2014).

10 UCDP captures minimum casualties of between 25 and 999 and 1000 or more battle-related deaths per year, which are coded at intensity levels 1 and 2 respectively. UCDP/PRIO Armed Conflict Dataset Codebook, Version 4-2015, Uppsala Conflict Data Program: 8.

11 According to the Human security report 2013, the number of drug-related deaths in Mexico, which account for about $46 \%$ to $60 \%$ of all homicides there, have since 2008 exceeded the deaths from war in Afghanistan, Sudan and Iraq, the three countries worst affected by armed conflict and violence globally (Simon Fraser University, www.hsrgroup.org/human-security-reports/2013/text.aspx: 52, [accessed 6 August 2014]). However, these numbers need to be placed in relationship to the size of the respective populations: Mexico at that time had a larger population than all three other countries combined.

12 See, for example, Chester Crocker, The strategic dilemma of a world adrift, in Survival, International Institute for Strategic Studies, London 57(1), February-March 2015: 7-30.

13 The number was 52755 in 1998.

14 The increase in the number of reported conflict events does not necessarily indicate an increase in violence, since different media outlets may report the same event. Furthermore, since ACLED uses many different media sources, it is possible for a story to be picked up more than once (if a particular source publishes an article that originated from a different source), even though extensive data cleaning is done.

15 Although Asia has the highest number of armed conflicts in absolute terms, given its large population.

16 For example, see Lotta Themnér and Peter Wallensteen, Armed conflict, 1946 - 2010, Journal of Peace Research, 48(4), 2011: 525-536.

17 Jakkie Cilliers and Julia Schünemann, The future of intrastate conflict in Africa: More violence or greater peace? ISS paper no. 246, May 2013: 16, www.issafrica.org/publications/papers/the-futureof-intrastate-conflict-in-africa-more-violence-or-greater-peace: 3 (accessed 31 August 2015).

18 UCDP, Non-state conflict codebook, version 2.5-2014, www.pcr.uu.se/digitalAssets/124/ 124930_1ucdp-non-state-conflict-dataset-codebook-v2.5-2014.pdf (accessed 21 July 2014).

19 Jakkie Cilliers and Julia Schünemann, The future of intrastate conflict in Africa: More violence or greater peace? ISS paper no. 246, May 2013: 16, www.issafrica.org/publications/papers/the-futureof-intrastate-conflict-in-africa-more-violence-or-greater-peace: 3 (accessed 31 August 2015).

20 Hävard Hegre, Joakim Karlsen, Hävard Strand and Henrik Urdal, Predicting armed conflict, 2010 2050, International Studies Quarterly, 2012:4.

21 Barry B Hughes, Devin K Joshi, Jonathan D Moyer, Timothy D Sisk, José Solórzano, Strengthening governance globally: The next 50 years, Vol. 5 - Patterns of potential human progress, Paradigm, Boulder, 2014, www.issafrica.org/futures/books/patterns-of-potential-human-progress-volume-5governance. The governance capacity index is an unweighted average of government revenue, net of aid recipients, as a portion of Gross Domestic Product and government corruption (using data from Transparency International).

22 Ibid., 28. For a detailed explanation see pages 88-92. 
23 Jakkie Cilliers and Timothy Sisk, Assessing long-term state fragility in Africa: Prospects for 26 'more fragile' countries, ISS Monograph 188, 27 November 2013, Chapter 2, www.issafrica.org/ publications/monographs/assessing-long-term-state-fragility-in-africa-prospects-for-26-more-fragilecountries

24 Barry B Hughes et al, Strengthening governance globally. The governance inclusion index combines measures of regime type and gender empowerment. Ibid., 32-39. For a detailed explanation see pages 92-96.

25 Ibid., 32.

26 Polity places its emphasis on the authority characteristics of regimes and therefore adopts a relatively thin definition of democracy. See www.systemicpeace.org/inscrdata.html.

27 Shortly before the Arab Spring, work by the African Futures Project pointed to the instability inherent in the large democratic deficit in the MENA region. Jakkie Cilliers, Barry Hughes and Jonathan Moyer, African Futures 2050, ISS, Pretoria, 27 January 2011: 69, www.issafrica.org/ publications/ monographs/african-futures-2050.

28 Ömer Taşpınar, Fighting radicalism, not 'terrorism': Root causes of an international actor redefined SAIS Review, XXIV(2), Summer-Fall 2009: 78-79.

29 In general, the data and analysis on terrorism remains largely concerned with actions directed at Western assets, although al-Qaeda and the Islamic State have become global threats that continue to evolve.

30 See the OAU Convention on the Prevention and Combating of Terrorism, Articles 1.3 and 3.

31 Roland Marchal, Boko Haram and the resilience of militant Islam in northern Nigeria, NOREF Report, Nordic International Support Foundation, June 2012: 1.

32 Yinka Ibukun and Chris Kay, Nigerian water shortage is bigger killer than Boko Haram, www. bloomberg.com/news/articles/2015-01-26/nigerian-water-shortage-is-bigger-killer-than-boko-haramcities, 26 January 2015 (accessed 8 August 2015).

33 Moriz Hütte, Guido Steinberg and Annette Weber, Boko Haram: Threat to Nigeria and its northern neighbours, in Guido Steinberg and Annette Weber (eds), Jihadism in Africa, SWP research paper, June 2015: 93; Prem Mahadevan, Resurgent radicalism, in Oliver Thränert and Martin Zapfe (eds), Strategic Trends 2015, Center for Security Studies, ETH Zurich, 2015: 54.

34 Ömer Tașpınar, Fighting radicalism, not 'terrorism', 76: Root causes of an international actor redefined SAIS Review, XXIV(2), Summer-Fall 2009.

35 Ibid., 79.

36 J Stern and J Berger, ISIS: The state of terror, William Collins, London, 2015: 202

37 GTD defines terrorism as the 'threatened or actual use of illegal force and violence by a non-state actor to attain a political, economic, religious or social goal through fear, coercion or intimidation'. Global terrorism database, Codebook: Inclusion criteria and variables, August 2014: 8, www.start. umd.edu/gtd (accessed 3 July 2015).

38 Calculated using ACLED data. 


\title{
Subscribe to the ISS for the latest analysis, insight and news
}

\author{
We're improving human security in Africa with authoritative research, \\ training and expert policy analysis
}

Step 1: Go to www.issafrica.org

Step 2: Under 'Subscribe to the ISS,' click on 'Email subscriptions'

Step 3: Select the type of notices you would like to receive:

Latest from the ISS

- ISS press releases

- ISS Weekly newsletter

- ISS Today

- ISS Spotlight

ISS event invitations

- Seminars, ISS Addis Ababa

- Seminars, ISS Dakar

- Seminars, ISS Nairobi

- Seminars, ISS Pretoria

- Training courses

ISS thematic reports

- Peace and Security Council Report

- Regional Report: Central Africa

- Regional Report: East Africa

- Regional Report: ECOWAS

- Regional Report: Southern Africa

Or, subscribe by topic of interest (to receive press releases, spotlights, event invitations, and reports that deal with your chosen topic):

- African Futures

- Arms control and disarmament

- Conflict prevention and analysis

- Corruption and governance

- Counter-terrorism

- Crime and criminal justice

- International criminal justice

- Organised crime

- Peacekeeping and conflict management 


\section{About the author}

Jakkie Cilliers is the executive director of the ISS and head of the African Futures and Innovation section. He is an extraordinary professor in the Centre of Human Rights and the Department of Political Sciences, Faculty of Humanities at the University of Pretoria.

\section{About the ISS}

The Institute for Security Studies is an African organisation that aims to enhance human security on the continent. It does independent and authoritative research, provides expert policy analysis and advice, and delivers practical training and technical assistance.

\section{Acknowledgements}

\section{Hanns \\ Seidel \\ Foundation}

This paper has been made possible with support from the Hanns Seidel Foundation. The ISS is also grateful for the support of the following members of the ISS Partnership Forum: the governments of Australia, Canada, Denmark, Finland, Japan, Netherlands, Norway, Sweden and the USA.

\section{ISS Pretoria}

Block C, Brooklyn Court 361 Veale Street

New Muckleneuk

Pretoria, South Africa

Tel: +27 123469500

Fax: +27 124600998

\section{ISS Addis Ababa}

5th Floor, Get House

Building, Africa Avenue

Addis Ababa, Ethiopia

Tel: +251115156320

Fax: +251115156449

\section{ISS Dakar}

4th Floor, Immeuble Atryum Route de Ouakam

Dakar, Senegal

Tel: +221 33860 3304/42

Fax: +22133860 3343

\section{ISS Nairobi}

Braeside Gardens off Muthangari Road Lavington, Nairobi, Kenya Cell: +254 728607642

Cell: +254 735650300

www.issafrica.org

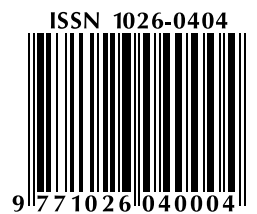

